\title{
A STUDY OF COLOUR AS AN ATTRIBUTE THAT INTENSIFIES USER'S ENGAGEMENT IN GAME PLAYS
}

\author{
Jude J.L. Martinez, Erwin Adi and Aloysius Theo Prima \\ BINUS University, Indonesia
}

\begin{abstract}
The Game industry in developing countries such as Indonesia was usually categorized as a small industry. Developers needed to find efficient techniques to make addictive games without having to spend many resources to overcome the complexity of the art and music. The purpose of this research was to seek and define the importance of colour as one of many aspects in designing a game for consumers and how it contributed to intensifying their engagement in games. The results showed discrete proof on how players of a certain age have different colour perceptions. In order to stimulate excitement while playing the game, the study showed that colour could be used to convey information. In conclusion, the results showed interesting facts about the correlation of colour and type of games.
\end{abstract}

\section{KEYWORDS}

Game design, colour perception

\section{INTRODUCTION}

The gaming industry plays an important role in the world economy. The growth of the global gaming industry revenue in 2006-2007 reached $28.4 \%$ [1]. On the contrary, the movies and music industries witnessed a fall in their revenues up to as much as $-10 \%$. The game market was not even shaken by the darkening of the 2008 global economic situation. With a growth of $13 \%$ that reached to a total value of $\$ 1.33 \mathrm{bn}$, the year 2008 was known as a record-breaking year for the game market in the US [2].

Among the Asian countries, where online game penetration is considered low, Indonesia may be placed as having the highest growth in the game industry. This indicator served as a sign of a high growth of what makes up the game components such as design, content provider, hardware, reusable software, etc. Furthermore, a non-profit organization that served as an association for the multimedia industry has recently started up the first rendering farm in Indonesia. Although the operational cost was forecasted to be higher than the association could afford, its chairman was confident that donations from potential users would exceed the break-even operational cost of 5,000 USD per month [4]. This courage indicated an initial stage in the boom of the digital animation industry in Indonesia.

Game developers in Indonesia were usually home-based and categorized as small industries. Nevertheless, some of them were hired by international game sponsors. The developers in Indonesia still met with some obstacles regarding the development of online games. As it was 
The International Journal of Multimedia \& Its Applications (IJMA) Vol.4, No.2, April 2012

stated at the Indonesian Game Developers Gathering, some of the obstacles were not the innovations or creativity of the developer, but rather the funding support, marketing strategy, and also support from the Indonesian Government [3]. This suggested that there was a need to have some knowledge in designing low-cost, yet entertaining games.

Within the field of Human Computer Interaction (HCI), many design strategies had been created by a number of experts such as, the Eight Golden Rules by Ben Shneiderman, Norman Principle of Design by Don Norman, Nielsen Heuristic by Jakob Nielsen, and many more. All of these rules were designed to be used in certain situations such as how colour should be used to avoid the user pressing a wrong button, how a natural set of an interface gave natural interaction for users to navigate, and how accessibility options could provide the users with computing tasks in different environments.

However, little study has been done on HCI knowledge for games, especially in Indonesia where the game industry was in its infancy. Knowledge on how users perceived games could help to design an attractive game that could draw attention to many players from different backgrounds. We assumed that a black and white coloured game would not attract too much attention for the players who see it (even though the gameplay was exciting) compared to a game that provides the player with a variety of colour schemes in their game. We observed that games for toddlers had different colour attributes than those for young adults. On the other hand, games with monochromatic colour schemes with less variety in the game that had many kinds of detail (e.g. shading, shadow, texture, detailed building, flashy gun effect, motion blur, etc.) attracted teens and young adults, who loved to go for a challenge or had a sense of adventure and exploration.

Noticing this condition we viewed an opportunity to find and gather all available resources and knowledge that other researchers had achieved, and combined it into one source in a way that game developers, researchers, and enthusiasts could see the results of the findings as their guideline to make the games. The purpose of this research was to seek and define the importance of colour as one of many aspects in designing games for consumers.

The following were the variables that we collected:

1. The age group/classification based on the Entertainment Software Rating Board (ESRB) Rating given to every game.

2. The rank given to any game is based on the score given by the professional game critics and by the game players

3. Three age group ratings, namely Teen, Mature, and Everyone.

4. 60 different games will be used as input samples, with 10 screenshots from each game taken randomly from the games.

Colour matrix data was using HSV (Hue, Saturation, and Value) that was converted from RGB colour spaces. The colours were extracted using ImageJ, a Free Image Processor that was developed using Java. The result data consisted of numbers that represented the HSV for each genre and range of colours for each genre.

\section{Problem Analysis}

Usually, game developers in Indonesia started their companies with less than 5 persons. With limited background in designing good interfaces and preparing colour schemes, the game 
The International Journal of Multimedia \& Its Applications (IJMA) Vol.4, No.2, April 2012

developers needed some time to do constant research for good colour schemes or interfaces on their games. This situation took time to get good results and also required a lot of funding.

Since the government only gave their support to creating the competition such as the Indonesian ICT Awards (INAICTA), instead of giving funding directly to the industry, this would only give game developers in Indonesia one choice and that is to fund for themselves in order to get the game company started.

\subsection{Government Support for the Game Industry in Indonesia}

The Indonesian Government only gave limited interest to the gaming industries $[4,5]$. This fact can be seen in the Creative Industry's average income from 2002 until 2006 which was around USD 8.7 billion or around $4.7 \%$ of the GDP. The Creative Industries consisted of Fashion, Traditional Handicraft, Research and Development, and 12 other industries namely Advertisement, Architecture, Arts, Theatre, Design, Software Development, Film, Music, Television and Radio, Publisher, Toys and Video Games.

These twelve (12) industries were categorized only to provide $10 \%$ of the Creative Industry's GDP Furthermore; the order also represented the annual income of each class. Lack of promotion was one of many reasons that the game industry only gave a small income compared to the whole of the creative industries. The game market in Indonesia was dominated by games from America, Japan, Korea and Europe. A recent interview with Toge production, one of the game developers in Indonesia, stated that they were eager to release their game on Indonesia's market since it was easier to make a game with an international flavour and also easier to find sponsors in international markets; Toge preferred to release their game overseas rather than in Indonesia.

The Government support on eliminating pirated software was also minimal for the benefit of the game developer. This situation made the game developer prefer to sell to the international market to release their games.

Seeing the growth of Internet usage around the world, the American Game Developers tried to face these problems via online access features. Some Game Developers such as, Treyarch and Infinity Wards, who developed the Call of Duty Franchise game, used the internet as their main weapon to fight back the hijacked version of their games. They implemented the online multiplayer game that could only be played online; a lobby called Steam that was developed by Valve. Despite all of these efforts, the games keep being hijacked and even hackers create their own Private servers in order to get Multiplayer features to work.

Pirated games being shared easily either on the internet or by using a flash disk or external hard drive, is not the case of Online Games in Indonesia. Online games have what we call a client in order for the gamer to play the game. With the full game located on the public server and not easily being hijacked, online games is a better choice for game publishers such as lyto, bolehgame, etc. to invest their money. Still, the Online Games that are legal in Indonesia are mainly dominated by Games from Korea and China such as Ragnarok online, Seal Online, Gunbound, etc. The Good point about having these online games is that all of their features are kept on the server and can only be accessed using client games distributed freely from the game publisher or it can be downloaded from the website or bought with a very cheap price, which never exceeds Rp. 5,000. Sadly, seeing these markets full of overseas competitors makes the local game developers struggle on their own especially in terms of financial issues. The reason why there are so many online games from Korea is because their government supports them. In 2008 
The International Journal of Multimedia \& Its Applications (IJMA) Vol.4, No.2, April 2012

the Korean Minister of Culture, Sports, and Tourism invested around \$200 billion in South Korea's game industry until 2012 and reached a yearly export target of approximately $\$ 3.36$ billion [6][7]. Having their government support them, their goal of exporting their game had a strong impact on the market of online games in Indonesia. The increasing internet penetration in Indonesia also helped the Online Game market's demand to increase exponentially. The data in Table 1 shows that there are 17 online game publishers in Indonesia and they have published more than 30 games so far and are still increasing year after year. As seen in the table, there are only three (3) games that were developed by Indonesians and they are bl@zz World, Nusantara Online, and Lilo Online.

The Number of Gamers that were counted by one of the Online Game publishers in Indonesia shows that there were 6 million gamers who registered on their server [6]. Seeing the fact that those numbers only counted one of the publishers in Indonesia -where we have more than 15 Game Publishers that provide online game services- means we could assume that Indonesia has more than six(6) million gamers, whether it is an Online Gamer or Offline Gamer, not to mention Facebook gamers as well. Given that scenario, it paves the way for an opportunity for game developers in Indonesia to develop and invest in the gaming industry. The number of game developers in Indonesia is still increasing whether they are professional or amateur game developers. The professional game developers that contribute greatly in Indonesia are not many and they are as follows: Altermyth Studio, Manticore Studio, Agate Studio, Toge Production and Divine Kids.

2.2 Problems with the Current Games Looking at things from another point of view we can ask ourselves why Indonesian games that have been published on the market are not well accepted by most Indonesian people. There are several Games trying to penetrate the Indonesian market today as the rivals of overseas games. These games such as: Nusantara Online, and Lilo City.

\subsubsection{Nusantara Online}

One of the most popular online Indonesian games is Nusantara Online. This Game was developed by Sangkuriang Studio and Telegraph Studio. Sangkuriang Studio has sole responsibility for developing the engine while the other studio develops the game play and the Art Assets of the game. This game was finally released on 25th February 2010. Despite being successful in publishing a game that uses the online community as its basis, this game has drawn many kinds of controversies. On the game developer side, this game could embrace 3D as its graphic engine and use the internet as its basis. But, on the other hand, on the customer side this game has drawn too many critics especially due to its graphics. This situation generally is caused by the influence of today's graphics style. Many critics say that this game comes with poor quality graphics compared to ones that are already on the market and furthermore, the critics stated that the game lacked the 3D aspect.

\subsubsection{Lilo City}

Lilo city is another popular online Indonesian game. Unlike Nusantara Online which has many critics, this game won an award at INAICTA 2008.[8]Despite winning the award, Lilo online has a lack of gameplay and interactivity since the game is only proposed as Virtual World Simulation. The players only have the capability for chatting and walking around the city game world. 
The International Journal of Multimedia \& Its Applications (IJMA) Vol.4, No.2, April 2012

\subsection{Opportunity Analysis}

Based on the Indonesian Game Catalogue there are more than 20 game developers that exist in Indonesia and all of them can be found in just 3 places: Jakarta, Bandung, and Jogjakarta [9]. Considering the total number of gamers which exceed 6 million players, and who love to play online games, the game developers could earn large revenues by selling their games on the Indonesian game market. Instead of publishing their games on the Indonesian market they just went directly to the internet. They tend to go directly to the internet because it pays higher than does selling it directly on the Indonesian market.

Main Games Studio is a game and animation studio located in Jakarta that once made a simple online game for a British website Miniclick. With only 2 persons needed to build the advert Online Game and a time frame of 1 month, this studio sold the game for $\$ 6,500$. A large amount for just an advert game where the main purpose of the developers is advertising their game with only a point and click game that uses the character and logo of the sponsor [9]. Seeing this possibility, with a small and very skilled human resource, an Indonesian game studio/developer could create a game that would sell well in Indonesia rather than overseas. To help 'newbie', game developers recently graduated from college or amateur game developers with only 2 to 4 persons on their team, developing a good guide has become a must for them. Creating a guide will help them produce a better game in no time. With an improvement in development time they can sell their game quickly and they will be able to produce more games than others who do not use the guide.

\subsection{Game Design Essentials}

Sid Meier, the father of the civilization game said in an interview that the starting point of a game designer when he wants to design a game is making a one sentence statement but it should not have any bond into the genre yet as well as the platform that should be used. By doing so, the possibility of creating more unique gameplay is greater. After the statement of the game is created, the team should discuss the best method to bring the game to reality. [10] Even though making a statement like Sid Meier did is a good idea, working through many possible ways is also acceptable.

There are three (3) points that should be considered when designing a game; they are Gameplay, Technology, and Story. All games need these 3 points, but, arranging the order of these components differently needs a different approach to maintaining the project.

\subsubsection{Gameplay}

One of the starting points when designing a game is by knowing what the game should do when being played by the players. A statement such as "Let's make a Racing Game!" or "It's a first person shooter like Doom!" [11] Has also worked out well in the industry. This starting point is the most common way that game designers will design their game for the market. After the gameplay is decided the technology regarding the kind of engine that will be used is discussed. Not every gameplay needs a 3D engine to be realized as a game. Angry Bird is one of the games that still use a cartoon 2D engine as its game engine; there is no great difference visually whether the game is rendered on $2 \mathrm{D}$ or $3 \mathrm{D}$. 
The International Journal of Multimedia \& Its Applications (IJMA) Vol.4, No.2, April 2012

\subsubsection{Technology}

Preparing the technology first to be developed and ready such as a game engine is a fairly common occurrence in designing games. The engine could come from the development team's first project or an "updated" version of an old engine or from a group of experimental researchers that has expertise in a certain field such as Physics calculation, Artificial Intelligence, 3D Real time, Render Engine, etc. By preparing the game engine first instead of the gameplay reduces the options of the gameplay, since there are some functions that the engine could not perform

\subsubsection{Story}

Each game must have a storyline, and the addressed problems are whether the storyline is clearly stated from the beginning up until the very end; and if it is interesting and able to attract the player; and if it is correlated to the main theme of the game. Starting game development by creating the story first is the less common way of creating a game, but will result in the game having strong story development. By developing the story first the story designer does not only think about how the movement of the story will be developed but also how the player/s could interact through the story and whether the player/s has/have the ability to twist the story as the player/s interact/s within what the players want[11].

\subsection{The Importance of Colour in Designing a Game}

A good set of colour palettes is a part of what makes games memorable. It also helps players express themselves and players can pick and settle down with their personal favourites to use as they grow more attached to the character and the game as a whole. It is also important for presentations where people are able to see colours other than the standard $1 \mathrm{P}$ and $2 \mathrm{P}$ palettes, something as simple character colour can add a lot to the player's enjoyment of the game.

Designing a Game is considered as the process of designing the rules on how to play; Richard Rouse III said game design is design that will determine every detail of how the gameplay will function.

According to Bangemann, there are 2 classifications for a colour when being used while designing a game, Distinct Colour and Colour Situation [1].

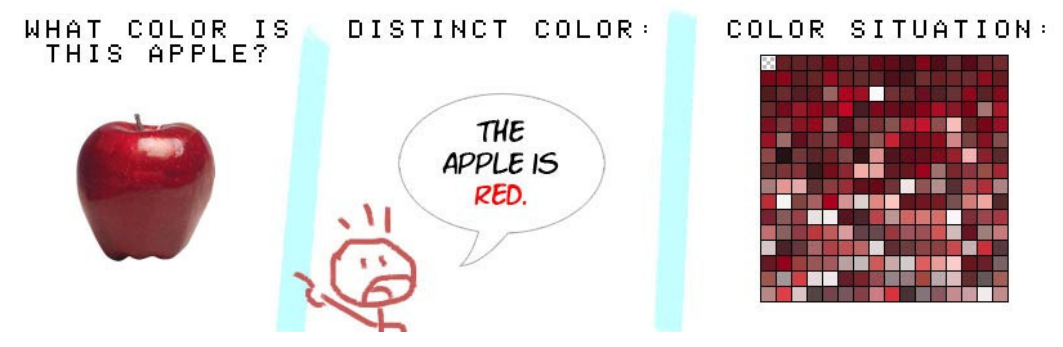

Figure 1. Examples of Distinct Colour and Colour Situation (source: www.HowToNotSuckAtGameDesign.com )

A distinct colour is a colour that can be easily recalled in one's daily conversation, so a primary colour on the Colour Wheel may also be called a Distinct Colour because we know the name of the colour verbally. A secondary colour can also be recognized as a Distinct Colour; on the other 
The International Journal of Multimedia \& Its Applications (IJMA) Vol.4, No.2, April 2012

hand a tertiary colour can partly be recognized as a distinct colour. The combination of $2 / 3$ red colour and $1 / 3$ Yellow colour can be called orange, while the combination of the $1 / 3$ Red colour and $2 / 3$ Yellow colour could also be called orange. That is why the tertiary colours are hard to recognize as distinct colours. But even though tertiary colours are generally hard to recognize as distinct colours there are some that can be so recognized, and they are brown, pink, flesh colour (or skin colour), silver, gold, turquoise and rainbow colour (primary and secondary colours in sequence), sepia and khaki.

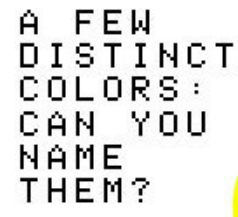

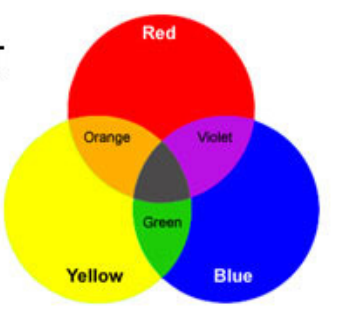
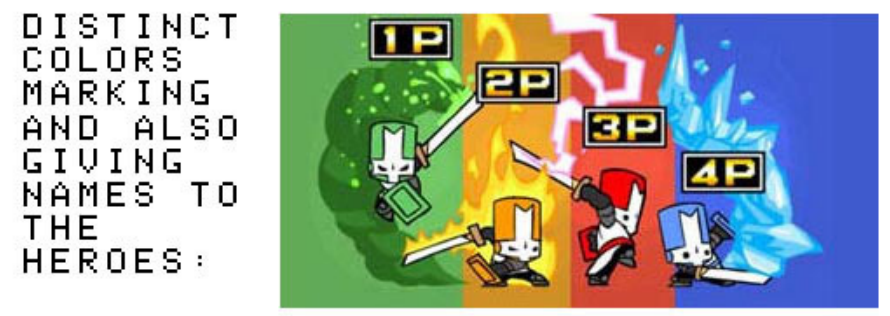

Figure 2. Example of using the Distinct Colour (source: www.HowToNotSuckAtGameDesign.com )

Another Classification of colour is the Colour Situation. In contrast to Distinct Colour, the Colour Situation impacts more on the subconscious level of the player rather than being recognized as part of everyday speech. The reflection of light, the combination of colour, and the complexity of the hue, etc, combined become one and try to stimulate the player's brain. That is where the colour situation comes into play. For example, the vibrant colours of an inhabited island with a combination of green and fruity colours indicate that there is a life form on that island or indicate that someone could survive on that island. On the contrary, a de-saturated environment, gray scenery, or a monochromatic colour scheme emphasizes that the player is at a stage wherein there are ruins or the player is about to enter to an evil lair. Another example is the use of Monochromatic Red to emphasize a dramatic scene, using bright red on screen to emphasize a hit or an attack; red is used to symbolize pain on the surrounding screen since it represents blood. All of these kinds of examples are something that has been recorded into players' subconscious minds and players' real life situations. The right tool to control the mood and to trigger it back is manipulating the Colour Situation.
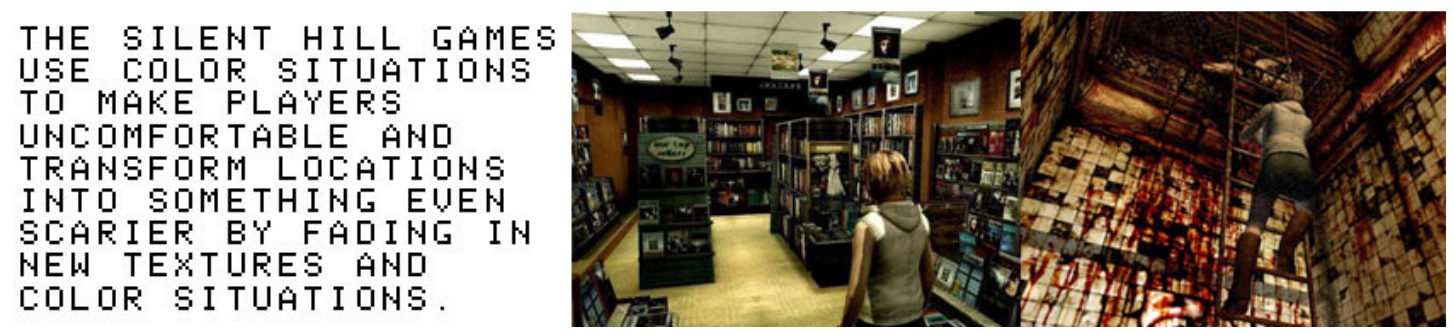

Figure 3. Implementation on Colour Situation concept (source: www.HowToNotSuckAtGameDesign.com ) 


\section{RESEARCH Methodology}

\subsection{Research Method}

The methodology that was used in this research was descriptive and exploratory. The way of collecting data in a descriptive manner was done by collecting numerical data on existing objects (in this case a Game). Using colour as the basis of research, the data collected were numerous types of screenshots of the game itself extracted using Image processor software via histogram data. One image was extracted into 3 types of colour channels, namely Red, Green, Blue and every channel's data was extracted using a Histogram. The exploratory methodology that was used in this research was in collecting information and knowledge related to the scope of the research. The collection of information and knowledge was completed using literature research, interviews, and observations through existing systems. The literature research was conducted by reading books, journals, articles, and scientific papers. Practitioners of the game industry in Indonesia were also requested to collect data on the problems that they experienced while making games. On observing the existing system, reading the user reviews of the system was utilised, in this case a specific game. Another way of observing the existing games was by looking at the game reviews giving the top ten ranks in each genre and seeing the cumulative rating that users give to certain games from more than one source.

\subsection{Population and Sampling}

The population of respondents of the interview are practitioners of the game industry in Jakarta. Furthermore, game players were also interviewed.

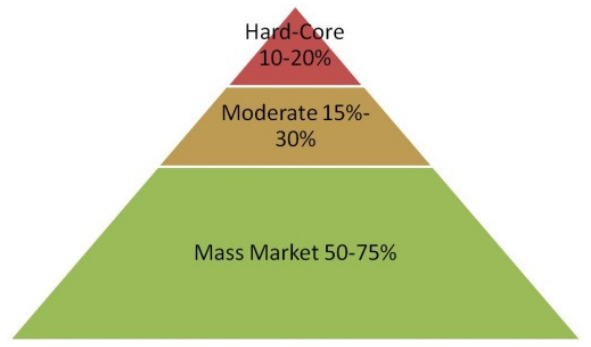

Figure 4. The Pyramid of gamer classification (source: www.industrygamers.com)

DFC, the writer on www.industrygamers.com divides gamers into 3 categories, namely Hard Core Gamer, Moderate Gamer, and Mass Market Gamer. The division can be seen in Figure 4 where Hard Core Gamers have a $10-20 \%$ proportion on the peak of pyramid, $15-30 \%$ of the moderate gamers sits in the middle, and the mass market takes the largest proportion at the base of the pyramid.

On sampling the data, the images were taken using screenshots a feature found in every game that exists on the market today. The screenshot was from a game session that a player had while playing the game. Thus, the extracted screenshot emphasized the player's view of the game. The screenshot samples that were taken were based on users' reviews and rankings of the game on game reviewer websites. More than one game reviewer website was sampled and the average rank was calculated to account for the different tastes of every individual user reviewer when seeing the image. After the average rating was measured, the top ten ranked games were sampled and measured. 
The International Journal of Multimedia \& Its Applications (IJMA) Vol.4, No.2, April 2012

\subsection{Data Collection Method and Design}

The data collection method that was used to carry out this research was data sampling using screenshots of every game grouped into each genre. The resultant data were based on every genre. The game that was sampled was among the top ten most popular games that were listed in several top ten rank game reviews on the internet. On every web game reviewer site there are a number of ratings that show how good the game is and the review of the game itself. There are 2 kinds of reviews: one from the website owner and the other comes directly from the users themselves who give their own opinions about the game and also a rating for it. The games that were sampled were the ones that were rated by the users in order to obtain what gamers see about these games directly. The minimum number of games that were used as samples for each genre was 10 and for each game the minimum number of screenshots taken was also 10. By doing so the accuracy of the results is more reliable for the market because there is a reason why the games are played by so many people worldwide.

Screenshots were gathered either directly from the computer or taken from the users who took screenshots of the screen while playing. The maximum amount of screenshots per game numbered15 pictures. Each picture was divided into 3 channels, Red Channel, Green Channel, and Blue Channel using ImageJ free image processor. On every channel, the histogram data was extracted and every channel's tabular data measured from level 0 - level 255 of the colour intensity for each pixel.

The Collected data was processed in 2 separate ways. First, the data that was collected was transferred into excel format and used to search for the MEAN from the extracted pictures' data for every channel. MEAN data is calculated using the Mathematical Formula in figure 5 to convert the calculated RGB channel into an HSV channel [25]

\begin{tabular}{|l|l||}
\hline Name & Mathematical Formula \\
\hline Hue & $H-\cos ^{-1}\left\{\frac{\frac{1}{2}[(R-G)+(R-B)]}{\sqrt{(R-G)^{2}+(R-B)(G-B)}}\right\}$ \\
\hline Saturation & $S=1-\frac{3}{R+G+B}[\min (R, G, B)]$ \\
\hline Value & $V=\frac{1}{3}(R+G+B) \mid$ \\
\hline
\end{tabular}

Figure 5. The RGB to HSV formula

Second, the authors calculated the MEAN for every channel and for every frame of the pictures that were extracted. Each picture's RGB channel was converted into an HSV channel. After the HSV channel was converted, the MEAN of the HSV was calculated. By performing the calculation on both approaches the authors wanted to find the difference in the results of both, and calculate the real average number of the HSV channel. The RGB Channel data that was collected was not only used for conversion into the HSV channel but was also used to analyze the colour information of every game genre. In analyzing the colour information the authors hope to find the unique characteristics of every game genre. 
The International Journal of Multimedia \& Its Applications (IJMA) Vol.4, No.2, April 2012

\section{RESEARCH FINDINGS AND ANALYSIS}

By using 600 data frames that have been gathered from the game as the main resources, the authors want to prove/find the following:

1. Colour is an important aspect in designing a good game

2. Colour can be used as a tool to enhance the excitement of a game

3. Optimal colour usage analysis on intense and non-intense environment in designing a game shows an effect on stimulating the excitement of players in a game.

The data were processed using an image software editor called ImageJ. All 600 frames of screen shots, the RGB Channel Histogram, the RGB Mean and Standard Deviation results were extracted and converted into HSV.

\subsection{Statistical Data Analysis}

The data sampling methodology for sampling the frame data used score rankings on game reviewer websites where the scores of the games that had been gathered from many popular game critic websites were summarized from the point of view of game critics and the players themselves. Thus, using the scores as the matrices on data sampling, the top twenty ranks of the game were selected on each of 3 kinds of rating, namely Mature (M), Teen (T), and Everyone (E).

Table 1. Data Collection Results

\begin{tabular}{|l|l|}
\hline Information & Total \\
\hline RGB Histogram data & 600 \\
\hline $\begin{array}{l}\text { RGB Mean and Standard } \\
\text { Deviation data }\end{array}$ & 600 \\
\hline $\begin{array}{l}\text { HSV Mean and Standard } \\
\text { Deviation data }\end{array}$ & 600 \\
\hline
\end{tabular}

Table 1 shows all the types of information that have been gathered through the process. HSV will be used as the main metric for this analysis from here onwards.

The processed result will be divided into several groups, namely Age Group, Rank Group, and Scene Group.

\subsubsection{Intense and Non-Intense Environment Analysis}

In this analysis, the frame data were divided into age groups based on the ESRB Rating (M, T, and E). In order to prove one of the hypotheses "Colour could be used as a tool to enhance the excitement of a game," a T-Test was used to see the differences in the data. If the differences existed in the data, it could be concluded that the colour usage changes between intense scene and non-intense scene enhances the excitement of the game. Intense scenes are a collection of several 
The International Journal of Multimedia \& Its Applications (IJMA) Vol.4, No.2, April 2012

types of scenes such as, battle scenes, chasing scenes, boss scenes, etc. while non-intense scenes include the following but are not limited to exploring scenes, scene dialogues, and scene options.

Table 2. Environment Data Comparison Results.

\begin{tabular}{|c|c|c|c|c|c|c|}
\hline \multicolumn{3}{|l|}{ Type of Data } & Mean & Variance & Size & \multirow{3}{*}{$\begin{array}{l}\text { T-Test } \\
0.715238\end{array}$} \\
\hline \multirow{6}{*}{ MATURE } & Intense & HUE & 73.12633 & 2773.704 & 100 & \\
\hline & $\begin{array}{l}\text { Non- } \\
\text { Intense }\end{array}$ & HUE & 67.86649 & 2634.388 & 100 & \\
\hline & Intense & SAT & 0.15838 & 0.010211 & 100 & \multirow{2}{*}{1.0957} \\
\hline & $\begin{array}{l}\text { Non- } \\
\text { Intense }\end{array}$ & SAT & 0.177433 & 0.020027 & 100 & \\
\hline & Intense & VAL & 74.08819 & 1256.446 & 100 & \multirow{2}{*}{0.162582} \\
\hline & $\begin{array}{l}\text { Non- } \\
\text { Intense }\end{array}$ & VAL & 73.33931 & 865.2426 & 100 & \\
\hline \multirow{6}{*}{ TEEN } & Intense & HUE & 79.12533 & 2846.66 & 100 & \multirow{2}{*}{1.015863} \\
\hline & $\begin{array}{l}\text { Non- } \\
\text { Intense }\end{array}$ & HUE & 71.12363 & 3357.66 & 100 & \\
\hline & Intense & SAT & 0.160156 & 0.016744 & 100 & \multirow{2}{*}{0.41302} \\
\hline & $\begin{array}{l}\text { Non- } \\
\text { Intense }\end{array}$ & SAT & 0.168118 & 0.02042 & 100 & \\
\hline & Intense & VAL & 81.07669 & 1292.825 & 100 & \multirow{2}{*}{0.22698} \\
\hline & $\begin{array}{l}\text { Non- } \\
\text { Intense }\end{array}$ & VAL & 82.1176 & 810.3123 & 100 & \\
\hline \multirow{6}{*}{ EVERYONE } & Intense & HUE & 79.05429 & 2852.053 & 100 & \multirow{2}{*}{2.14117} \\
\hline & $\begin{array}{l}\text { Non- } \\
\text { Intense }\end{array}$ & HUE & 95.79741 & 3262.571 & 100 & \\
\hline & Intense & SAT & 0.200194 & 0.01489 & 100 & \multirow{2}{*}{0.69659} \\
\hline & $\begin{array}{l}\text { Non- } \\
\text { Intense }\end{array}$ & SAT & 0.214386 & 0.026618 & 100 & \\
\hline & Intense & VAL & 103.0896 & 1492.187 & 100 & \multirow{2}{*}{2.318887} \\
\hline & $\begin{array}{l}\text { Non- } \\
\text { Intense }\end{array}$ & VAL & 90.7081 & 1358.747 & 100 & \\
\hline
\end{tabular}

The T-Test in Table 2 indicates that EVERYONE has the biggest difference between Intense and Non-Intense Scenes, because most of the T-Test results were higher than two (2).It means that differences exist for whole population and not only for the sample.

\subsubsection{Age Group RGB Histogram Analysis}

In this analysis the sample that was used was the Histogram that was extracted directly from the frame data, which was the RGB data. These patterns cannot be seen until the RGB Histogram data were joined together into one document. The Pattern on the Histogram shows us that most of the $\mathrm{M}$ rating games have the tendency to be less colourful. These can be seen on each M Ratings frame's histogram, where there are fewer differences between each frame. Most of the RGB 
The International Journal of Multimedia \& Its Applications (IJMA) Vol.4, No.2, April 2012

Colours are located between levels 20 - 110, with some of them located on the upper level however; the number/frequency is low. On the other hand the $\mathrm{E}$ rating game data frame shows a big difference in the pattern. Each part of the E Rating Histogram data is different from each other. These conditions show that $\mathrm{E}$ rating games have big varieties in terms of choosing the colour. While the $\mathrm{E}$ rating games show significant changes among each of the frames the $\mathrm{T}$ Rating games show fewer changes than the E Rating games but have more changes than the $\mathrm{M}$ Rating games. Thus, the order from fewest to most having changes in their histograms are $\mathrm{M}, \mathrm{T}$, E. in other words the T Rating games are the transitions between M and E Rating games

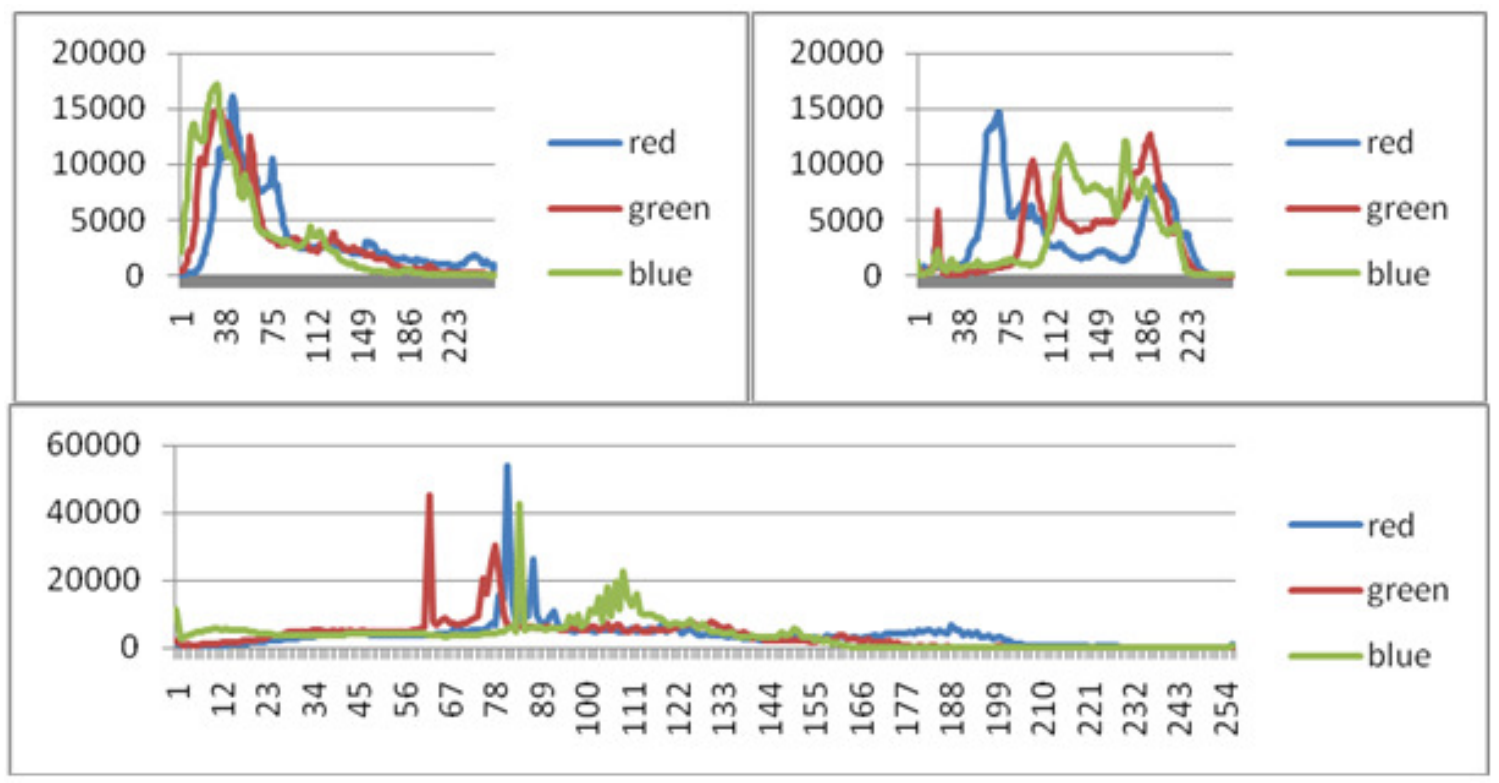

Figure 6. The Comparison Example of the Age Group Histogram games (Top Left: M, Right: E, Mid: T)

\subsubsection{Top ten rank and age group comparison analysis}

In this analysis the data was grouped based on their Age Group/Age Rating (The M, T, and E ESRB Rating) and categorized based on each rank that was given by the website reviewer. So after the data were categorized in each rank, nine (9) graphs were extracted as the result of the data. Each graph represents HUE, SATURATION, and VALUE respectively for each Age Group/Rating.

\subsubsection{HUE comparison results}

Figures 7, 8, and 9 show that the differences in the HUE usage emerged when the data was divided into each respective rank. The ranges of colours on the graph data show that the TEEN (T) Rating games have the widest ranges of colour usage when compare to the MATURE and EVERYONE ratings. 
The International Journal of Multimedia \& Its Applications (IJMA) Vol.4, No.2, April 2012

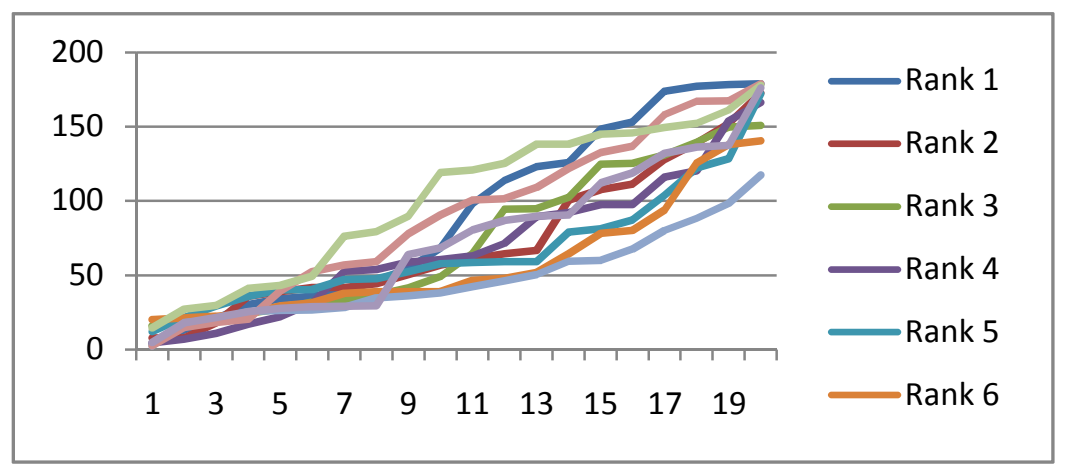

Figure 7. HUE on Age Group (E Rating) and Rank Comparison Data

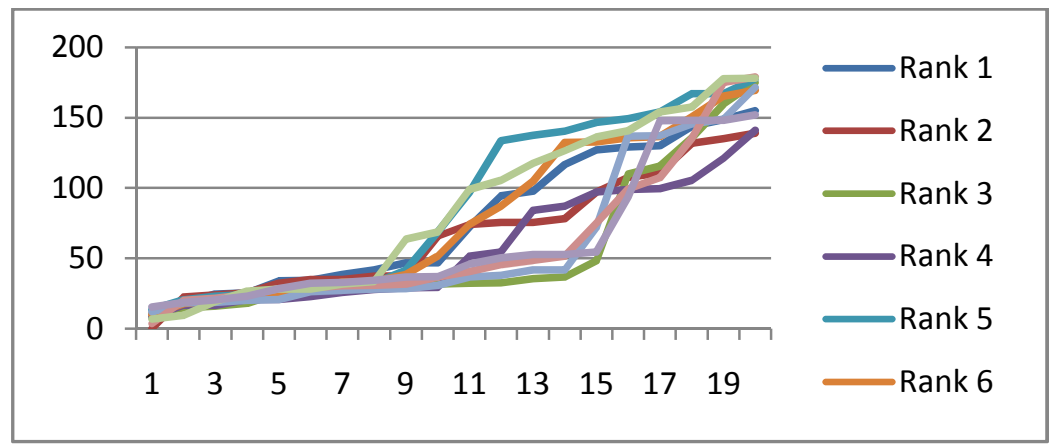

Figure 8. HUE on Age Group (M Rating) and Rank Comparison Data

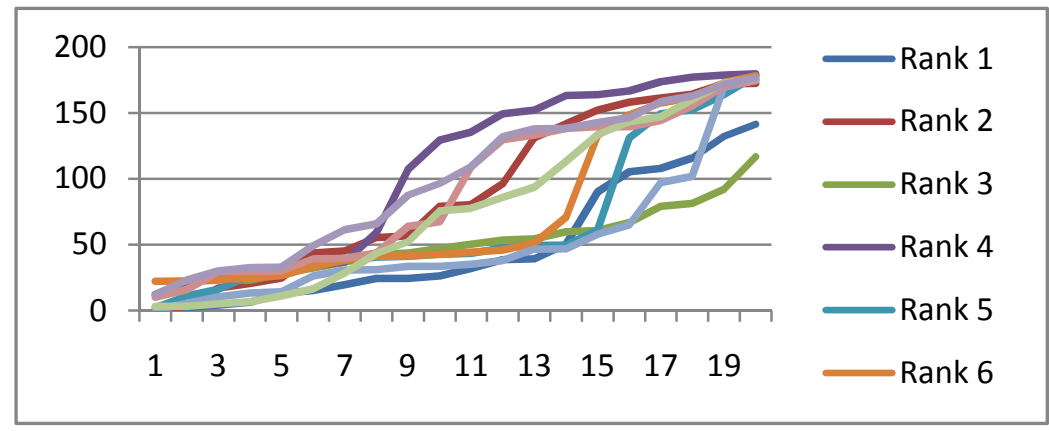

Figure 9. HUE on Age Group (T Rating) and Rank Comparison Data

\subsubsection{SATURATION comparison analysis}

Figures 10, 11 and 12 on the SATURATION graph data show that the EVERYONE (E) rating has the most Vibrant Colours on its games. The MATURE (M) rating has the less vibrant colour than the other graph data because most of the data remained below 0.2 levels of saturation while majority of the data ended on 0.3 levels, thus, making the colours look grayish and less colourful than the others. While on the other hand the TEEN (T) rating games have shown a little bit more vibrancy for some than the $\mathrm{M}$ rating games. This implies that some of the games are quite similar to the $\mathrm{M}$ rating games, meaning, game designers creating games for teenagers could use several approaches used from both kids and young adults. 
The International Journal of Multimedia \& Its Applications (IJMA) Vol.4, No.2, April 2012

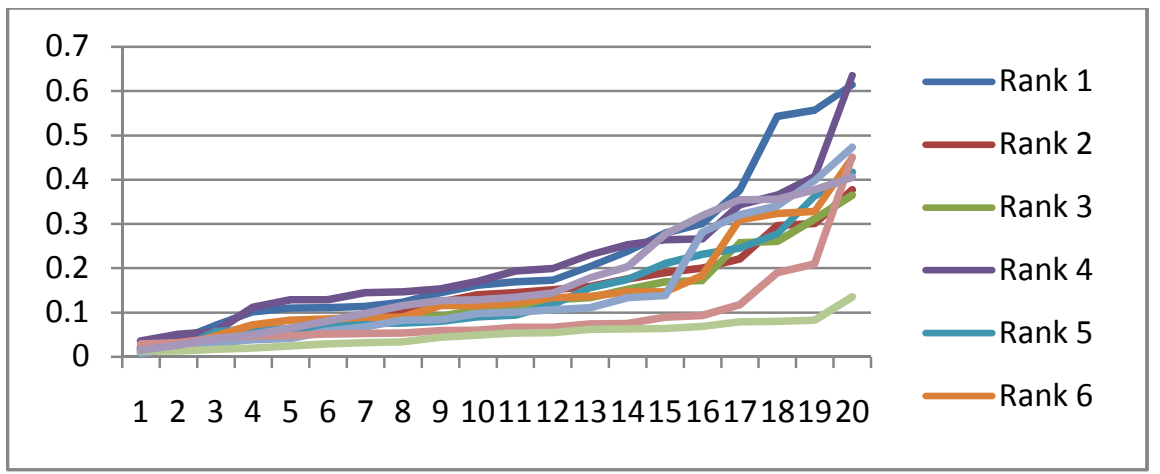

Figure 13. VALUES on Age Group and Rank Comparison Data (E Rating)

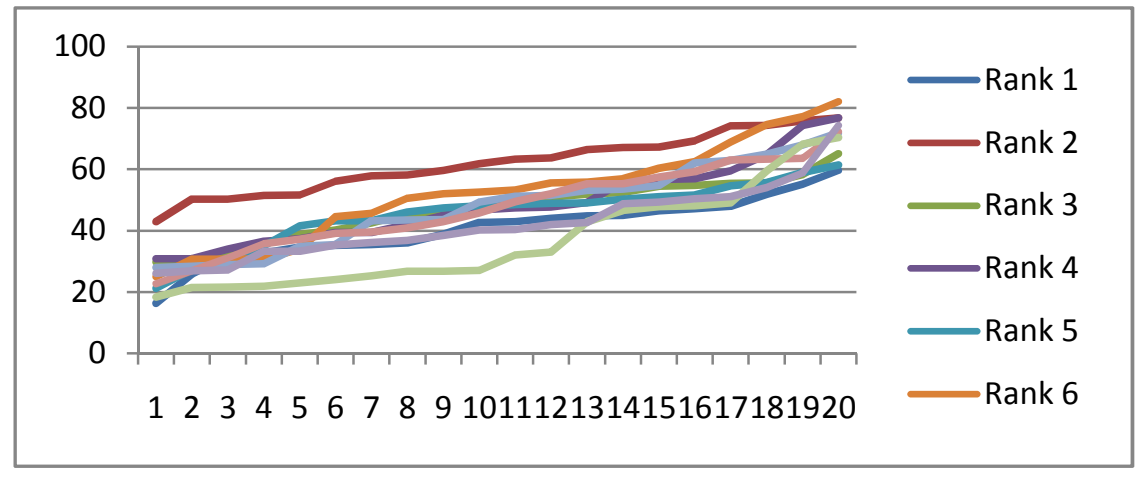

Figure 14. VALUES on Age Group and Rank Comparison Data (M Rating)

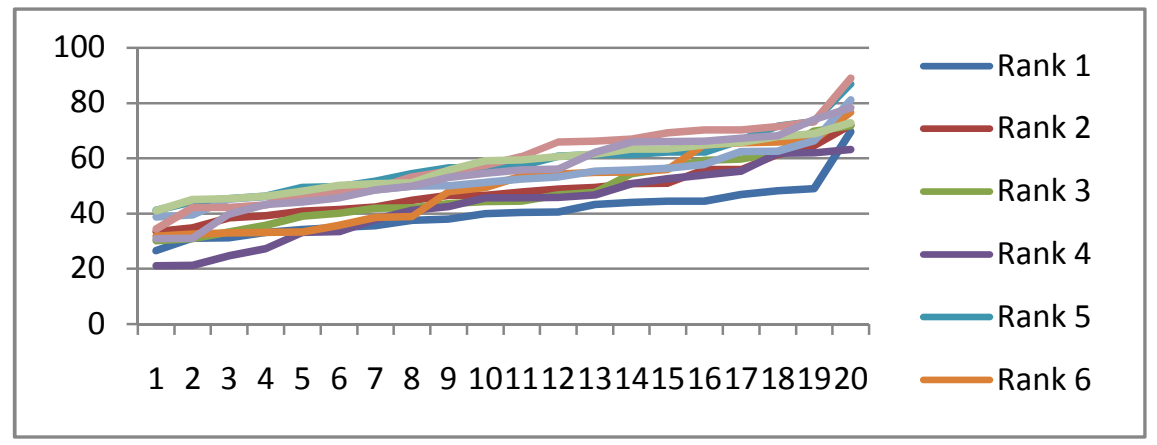

Figure 15. VALUES on Age Group and Rank Comparison Data (T Rating)

\section{DISCUSSION}

The topics that will be presented in this discussion are nonetheless the whole correlation between the Colour and the Age Group, thus this correlation affects the excitement of the game or not, and the importance of playing with colours when designing the game. It will be divided into the following:

1. Evaluation of the colour measurement standard between RGB and HSV 
The International Journal of Multimedia \& Its Applications (IJMA) Vol.4, No.2, April 2012

2. Colour having an effect on the stimulation of excitement when playing games at a certain age.

\subsection{Evaluation on the Colour measurement standard}

It has been ascertained that a game designer will find that using RGB as the measurement for evaluating colours may be less confusing or frustrating when wanting to pick a colour for a design. This result could be found using the VARIANCE test that has been measured from 600 data frames that have been extracted from 60 games

Table 3. RGB Comparison table on MEAN and VARIANCE results

\begin{tabular}{|l|l|l|l|l|l|l|l|l|l|}
\hline & RED $(\mathbf{M})$ & RED $(\mathbf{T})$ & RED $(\mathrm{E})$ & $\begin{array}{l}\text { GREEN } \\
(\mathbf{M})\end{array}$ & $\begin{array}{l}\text { GREEN } \\
(\mathbf{T})\end{array}$ & $\begin{array}{l}\text { GREEN } \\
(\mathbf{E})\end{array}$ & $\begin{array}{l}\text { BLUE } \\
(\mathbf{M})\end{array}$ & BLUE (T) & $\begin{array}{l}\text { BLUE } \\
(\mathbf{E})\end{array}$ \\
\hline MEAN & 79.19858 & 85.33737 & 98.11864 & 74.12023 & 75.39472 & 103.3255 & 67.82245 & 84.05936 & 89.25246 \\
\hline VARIANCE & 1239.064 & 1268.41 & 1637.231 & 1073.335 & 1157.331 & 1803.595 & 1175.343 & 1323.344 & 1815.743 \\
\hline $\begin{array}{l}\text { SAMPLE } \\
\text { SIZE }\end{array}$ & 200 & 200 & 200 & 200 & 200 & 200 & 200 & 200 & 200 \\
\hline
\end{tabular}

Table 4. HSV Comparison table on MEAN and VARIANCE results

\begin{tabular}{|l|l|l|l|l|l|l|l|l|l|}
\hline & $\begin{array}{l}\text { HUE } \\
(\mathbf{M})\end{array}$ & HUE $(\mathrm{T})$ & HUE (E) & SAT (M) & SAT(T) & SAT (E) & VAL (M) & VAL(T) & VAL(E) \\
\hline MEAN & 70.49641 & 75.12448 & 87.42585 & 0.167907 & 0.164137 & 0.20729 & 73.71375 & 81.59715 & 96.89885 \\
\hline VARIANCE & 2697.409 & 3102.658 & 3112.384 & 0.015134 & 0.018504 & 0.0207 & 1055.654 & 1046.557 & 1456.822 \\
\hline $\begin{array}{l}\text { SAMPLE } \\
\text { SIZE }\end{array}$ & 200 & 200 & 200 & 200 & 200 & 200 & 200 & 200 & 200 \\
\hline
\end{tabular}

Table 3 and 4 show that the VARIANCE Results on RGB are more stable than HSV since it can be seen that the results are similar, comparing them to the HSV results that have quite a large differences on the VARIANCE result. This result could be caused by the same metrics that the RGB has which range from 0 to 255 . While the HSV has different metrics on each variable it has, the HUE has Radiant or Degree as the metrics, the Saturation has $0-1$ as the metrics, while the Value has percentage as the metrics. The Graph Comparison Test between ranks on the same variable with certain patterns has been done to strengthen the proof, the pattern is:

1. Rank 1 Vs Rank 10

2. Rank 2 Vs Rank 9

3. Rank 3 Vs Rank 8

4. Rank 4 Vs Rank 7

5. Rank 5 Vs Rank 6

Using a T-Test as the comparison tool, the purpose of this test is to see which one is more stable between RGB and HSV using the same sample but with different variables. Figure 16 shows the 
The International Journal of Multimedia \& Its Applications (IJMA) Vol.4, No.2, April 2012

result of the test. Similar to the previous result between RGB and HSV on VARIANCE tests, this T-Test shows that RGB demonstrates more stability than HSV based on the graph' movement.

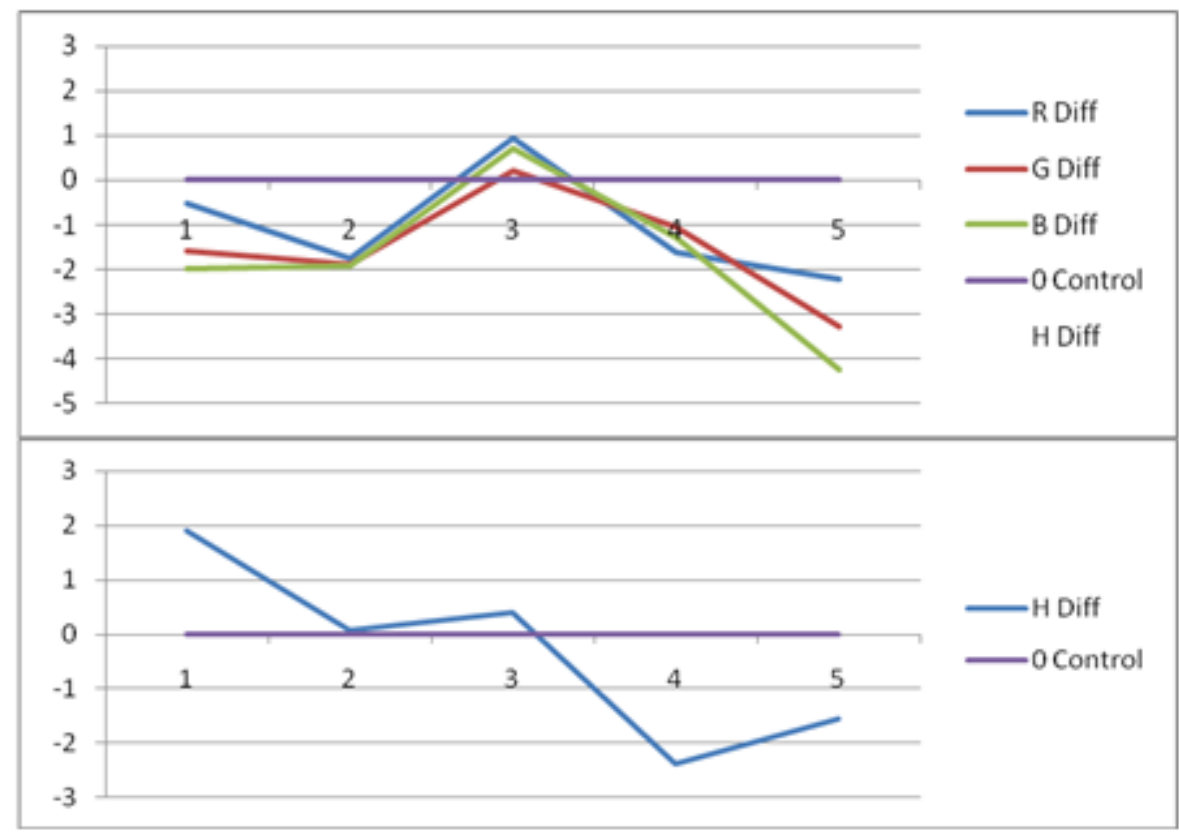

Figure 16. RGB and HUE T-Test Results (Per Rank)

The comparison results in graph 16 between High-Rank games and Low-Rank games show that High-Rank games have distinct colour properties compared with the Low-Rank games. Therefore, this proves the aim of this research that choice of colour has a direct relationship to or correlation with the rank of the game. However, the observation method cannot be obtained by using the T-Test results of the HUE, so RGB was used instead.

\subsection{The Colour has an effect on stimulating the excitement in playing games}

The analysis in table 3 (Environment Data Comparison) shows that colour has an effect on stimulating the excitement of players while playing games. Using a T-Test as the comparison formula, the results show that the $\mathrm{E}$ rated games demonstrate a difference between an intense scene and non-intense scene. The T-Test results in table 3 show that two out of three variables tested for each Age group demonstrate a difference greater than two (2), This suggests that colour does have an effect on the excitement level of the game, especially for games that are designed to be played by Everyone, including children. 
The International Journal of Multimedia \& Its Applications (IJMA) Vol.4, No.2, April 2012

Table 5. T-Test Results on Comparison between Intense and Non-Intense Scenes per Age Group

\begin{tabular}{|c|c|c|c|}
\hline \multicolumn{3}{|c|}{ TYPE of DATA } & T-TEST \\
\hline \multirow{6}{*}{ MATURE } & Intense & HUE & \multirow{2}{*}{0.715238} \\
\hline & $\begin{array}{l}\text { Non- } \\
\text { Intense }\end{array}$ & HUE & \\
\hline & Intense & SAT & \multirow{2}{*}{1.0957} \\
\hline & $\begin{array}{l}\text { Non- } \\
\text { Intense }\end{array}$ & SAT & \\
\hline & Intense & VAL & \multirow{2}{*}{0.162582} \\
\hline & $\begin{array}{l}\text { Non- } \\
\text { Intense }\end{array}$ & VAL & \\
\hline \multirow{6}{*}{ TEEN } & Intense & HUE & \multirow{2}{*}{1.015863} \\
\hline & $\begin{array}{l}\text { Non- } \\
\text { Intense }\end{array}$ & HUE & \\
\hline & Intense & SAT & \multirow{2}{*}{0.41302} \\
\hline & $\begin{array}{l}\text { Non- } \\
\text { Intense }\end{array}$ & SAT & \\
\hline & Intense & VAL & \multirow{2}{*}{0.22698} \\
\hline & $\begin{array}{l}\text { Non- } \\
\text { Intense }\end{array}$ & VAL & \\
\hline \multirow{6}{*}{ EVERYONE } & Intense & HUE & \multirow{2}{*}{2.14117} \\
\hline & $\begin{array}{l}\text { Non- } \\
\text { Intense }\end{array}$ & HUE & \\
\hline & Intense & SAT & \multirow{2}{*}{0.69659} \\
\hline & $\begin{array}{l}\text { Non- } \\
\text { Intense }\end{array}$ & SAT & \\
\hline & Intense & VAL & \multirow{2}{*}{2.318887} \\
\hline & $\begin{array}{l}\text { Non- } \\
\text { Intense }\end{array}$ & VAL & \\
\hline
\end{tabular}

While the E Rating games show a significant result in stimulating excitement by changing the scene of the game, the $\mathrm{T}$ rating games and $\mathrm{M}$ rating games show that there is only a small difference which exists between the Intense and Non-Intense scene. On the T rating it shows that the T Rating Game has a wider choice of HUE or type of colour. As is stated in Table 5, the TTest results on HUE value on T Rating shows 1.015 and on M rating shows 0.715 . Seeing these result, between $\mathrm{T}$ rating and $\mathrm{M}$ rating colour has less priority in designing a game. But, colour indeed has an effect on stimulating the excitement. This is simultaneously important and not-so important. It is not so important in the sense that it contributes to the gameplay, but something as simple as character colour palettes can add a lot to the player's enjoyment of the game.

\section{ConClusion}

Making a game cannot be based on exact theories. It should go through cycles of research, testing, and the incorporation of new ideas. There are many factors that can affect a good game. Fun is what is to be achieved in making a game so that people can get excited playing it. There is no other reason for people to play the game other than to have some fun.

The fun of the game can sometimes be the X-factor that can only be felt by particular people. Nevertheless, there are still ways to achieve that through upgrading the other factors that affect 
The International Journal of Multimedia \& Its Applications (IJMA) Vol.4, No.2, April 2012

the game such as, game play, visuals, storyline, etc. Ideas are found to play quite a big part in creating that fun factor. Unique, fresh, and new ideas should be added to the game.

The results of this research have shown along with observation results prove that colour is one of the important aspects in designing an interesting game to meet the needs of today's gamers. With the improvement of technology, both in computer hardware and software, the demand for making more interesting games with interesting visuals is increasing. The increase in demand in the game industry has led the game designer to create a more visually appealing game in order to compete with others. So, using Distinct Colour and Colour Situations could help the game designer create a game that could indulge and stimulate excitement in the gamer/player's mind and try to simulate the same situation for the player with the situation inside the game, so the game could have a more realistic nature.

Both RGB and HSV were the variables chosen to represent colour and also have great importance in their own way. But for a game designer, who likes to design game levels and combine them with colours to create colour scripts in order to help the 2D artists, RGB should be used as the tool to choose colour because RGB has more stable variables than HSV. But, for a measurement tool to check colour differences between each scene HSV is the most suitable variable. Hue, Saturation and Value could be used as measurements, because instead of pointing the combined value of Red, Green, and Blue on the RGB Colour Model which has many combinations, the HSV Colour Model has all the colours along with Saturation and Value.

Game developers can collaborate with the government to promote their games, while at the same time enliven Indonesian culture. This mutualism could support the game developers in overcoming their funding problems. Apart from funding, it is clear that game developers also have problems marketing their products.

\section{REFERENCES}

[1] Bangeman Eric. Growth of Gaming in 2007 far outpaces movies and music.2008.[Online] Available: http://arstechnica.com/gaming/news/2008/01/growth-of-gaming-in-2007-far-outpaces-moviesmusic.ars.[Accessed:12 January 2009].

[2] Parfitt Ben. NPD: January market sees 13\% growth. 2009. [Online] Available:http://www.mcvuk.com/news/33243/NPD-January-market-sees-13-growth. [Accessed: 12 January 2009].

[3] IDC Malaysia, "Free-of-Charge Business Model to Attract More Paying Online Gamers in Malaysia says IDC “, June 2006. [Online] Available:http://www.idc.com.my/PressFiles/IDC\%20Malaysia\%20\%20OnlineGaming.asp. [Accessed: 10 March, 2009].

[4] Adi, Erwin, "Render Farm Initiative", Indonesian Business Cases: From Innovation to Financial Excellence, Binus Publishing, Penerbit Salemba Empat, ISBN 978-979-061-125-2, Jakarta, 2010.

[5] Moehiddin, Ilham Q (2010, 18 June) Ketika Indonesia Berperang Tanpa Tameng [Online] Available at http://ekonomi.kompasiana.com/bisnis/2010/06/18/ketika-indonesia-berperang-tanpa-tameng/ [Accessed: 10th March 2011].

[6] Christian (2008, 5 Dec) Pemerintah Korea Investasikan \$200 Juta Dukung Industri Game [Online] Available at http://www.kotakgame.com/berita/detail.php?id=802 [Accessed: 25th April 2011]. 
The International Journal of Multimedia \& Its Applications (IJMA) Vol.4, No.2, April 2012

[7] Magrina, Tom $(2008,5 \mathrm{Dec})$ South Korea Plans \$200B game fund [Online] Available at http://asia.gamespot.com/news/6201947.html [Accessed: 25th April 2011].

[8] Christian (2008, 11 Aug) LILO raih game terbaik INAICTA 2008 [Online]

[9] Febrina, Annisa S. (2009, 15 Jun) the serious business of Online Games [Online] Available at http://www.thejakartapost.com/news/2009/06/15/the-serious-business-online gamess.html [Accessed: 8th March 2011]

[10] Christian (2008, 11 Aug) LILO raih game terbaik INAICTA 2008 [Online] Available at http://www.kotakgame.com/berita/detail.php?id=174 [Accessed: 17th March 2011]

[11] Rouse, Richard III "Interview: Sid Meier" Game Design: Theory and Practice,1st ed. Texas, wordware, pp $42-47$.

[12] Anhut , Anjin (2011, 13 Jan) Game and Swatch - Colour Theory for Game Designers part 1 Available at http://howtonotsuckatgamedesign.com/?p=1669 [Accessed: 4th February 2011]

[13] Anhut, Anjin (2011, 16 Jan) Game and Swatch - Colour Theory for Game Designers part 2 Available at http://howtonotsuckatgamedesign.com/?p=1702 [Accessed: 5th February 2011]

[14] Ford, Ryan (2007) Colour Theory Available at http://colourtheory.liquisoft.com/ [Accessed: 5th March 2011]

[15] Farrek, David (2010, 25 Oct) Game design 2 Lecture 5: Colour Available at http://www.slideshare.net/unthank/game-design-2-2010-colour [Accessed: 5th March 2011]

[16] Games, Epic (2010, 7 Mar) Colours within Game Design: Colours with Meaning Available at http://www.takeinitiative.co.uk/?p=863 [Accessed: 5th March 2011]

[17] Looney, Andrew (2003, Jan) Andrew Looney's Eleven Principles of Game Design Available at http://www.wunderland.com/WTS/Andy/Games/DesignPrinciples.html [Accessed: 5th March 2011]

[18] Omernick, Matthew (2004, 9 Jul) Lighting Principles for Game Design Available at http://www.peachpit.com/articles/article.aspx?p=174370 [Accessed: 27h March 2011]

[19] Gates, Bob, Game Design, 2nd Edition. Boston, MA : Thomson Course Technology, 2004

[20] Crawford, Chris (1982) The Art of Computer Game Design Available At http://library.vancouver.wsu.edu/sites/library.vancouver.wsu.edu/files/ACGD.pdf [Accessed: 25th April 2011]

[21] Hiryanto, Trisno (2009, 6 Feb) Game Online di Indonesia Makin Subur [Online] Available at http://www.detikinet.com/read/2009/02/06/093617/1080445/654/game-online-di-indonesia-makinsubur [Accessed: 16th March 2011]

[22] Rachman, Taufik (2010, 26 Aug) Indonesia Peringkat ke Lima Pengguna Internet di Asia [Online] Available at http://www.republika.co.id/berita/trendtek/telekomunikasi/10/08/26/132065-indonesiaperingkat-ke-lima-pengguna-internet-di-asia [Accessed: 22th April 2011]

[23] Magrina, Tom $(2008,5$ Dec) South Korea Plans \$200B game fund [Online] Available at http://asia.gamespot.com/news/6201947.html [Accessed: 25th April 2011] 
The International Journal of Multimedia \& Its Applications (IJMA) Vol.4, No.2, April 2012

[24] admin (2011, 18 jan) Daftar Game Online di Indonesia[Online] Available at http://www.bikinwarnet.com/games-online/daftar-games-online-di-indonesia.html [Accessed: 16th April 2011]

[25] Jeong, Sangoh (2001, 15 Mar) Histogram-Based Color Image Retrieval. Psych221/EE362 Project Report

\section{Authors}

Jude J.L. Martinez completed his Masters in Computer Science at De La Salle University, Manila. Thereafter, he devoted his time working in academia for more than a decade. Research interests include, but are not limited to, Mobile and Pervasive Computing, Software Engineering and its applications.

Erwin Adi teaches and coordinates Web Programming and User Interface Engineering classes in BINUS International - BINUS University. He was a network engineer for some multi-national companies in Belgium where he gained experience in handling fiber networks, controlling Europe-wide networks using various platforms, troubleshooting IP issues, and mitigating high-impact network failures. Erwin has a master's degree in Telecommunications from the University of Strathclyde in GGlasgow, UK and a double-major bachelor's degree in Computer

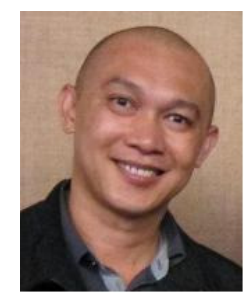
Science and Applied Mathematics/Statistics from the State University of New York at Stony Brook, USA, where he was in a Dean's List for three semesters and was invited into the Sigma Beta Honor Society.

Aloysius Theo Prima is a Freelance web designer and programmer who graduated from BINUS International - BINUS University, Jakarta, Indonesia with a bachelor's degree in Computer Science with a major in Multimedia and minor in Art and Design. He is currently employed as a programmer in a comic and animation studio named Main Studios. Having been playing games since he was born has inspired him to learn how to design a game with focus on controlling the color value and yet educating the players. Pursuing his dream to become a Professional

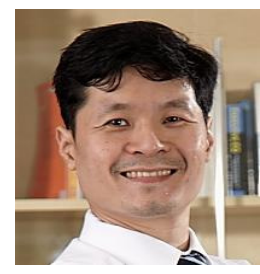
game maker, he decided to improve his knowledge and skills in Japan. 